Short communication

\title{
Thermal study of $\mathrm{ZrO}_{2}$ nanoparticles: Effect of heating and cooling cycles on solid-solid transition
}

\author{
Caroline Gaglieri, Rafael T. Alarcon, Rafael de Godoi Machado, David S.S. Padovini, \\ Fenelon M.L. Pontes, Flávio J. Caires*
}

Universidade Estadual Paulista (UNESP), Faculdade de Ciências, Bauru, Brazil

\section{A R T I C L E I N F O}

\section{Keywords:}

$\mathrm{ZrO}_{2}$ nanoparticles

Solid-solid transition

Thermal analysis

\begin{abstract}
A B S T R A C T
This study investigates the influence of particle size on the solid-solid transition in zirconium $\left(\mathrm{ZrO}_{2}\right)$ nanoparticles. The Simultaneous Thermogravimetry/Derivate Thermogravimetric-Differential Thermal Analysis (TG/DTG-DTA) was used to evince the phase transitions processes as well as the quantity of volatile compounds and the residual organic matter formed during the synthesis of nanoparticles. Field Emission Scanning Electron Microscopy (FE-SEM) and Transmission Electron Microscopy (TEM) were used to prove the increase and agglomeration ; 1 ;of particle size after each thermal cycle.
\end{abstract}

\section{Introduction}

Zirconia, or zirconium oxide $\left(\mathrm{ZrO}_{2}\right)$, is an important functional material that is widely used as a biofuel cell electrolyte, as a semiconductor in materials, and as catalyst support [1-5]. Interest in the study of zirconia is related to its unique properties, namely its polymorphic nature and acidic and basic properties, which depend on factors such as the type of heat treatment, refractory character, mechanical properties, antimicrobial agent, chemical stability and ionic conductivity [6-8].

At ambient pressure zirconia is found in the monoclinic phase $(\mathrm{m})$, which is stable until approximately $1170{ }^{\circ} \mathrm{C}$. Close to this temperature occurs the transition to tetragonal phase $(m \rightarrow t)$, which is stable until $2370{ }^{\circ} \mathrm{C}$. The tetragonal to cubic transition $(t \rightarrow c)$ occurs above $2370{ }^{\circ} \mathrm{C}$ and this phase is stable up to $2680{ }^{\circ} \mathrm{C}[9,10]$. In literature it is related that under cooling conditions the tetragonal phase is transformed in monoclinic phase near $950{ }^{\circ} \mathrm{C}$ [9].

The use of zirconia depends of its phase. The cubic phase is used in the determination of thermodynamic parameters, whereas the tetragonal phase is applied as a cutting and grinding tool. The monoclinic phase can be applied in $\mathrm{CO}$ adsorption $[11,12]$. All the $\mathrm{ZrO}_{2}$ phases are applied as catalyst or catalyst support. Consequently, it is important to have information regarding the thermal behavior of the different phases.

No reports were found in the scientific literature regarding the thermal behavior of $\mathrm{ZrO}_{2}$ nanoparticles under various heating and cooling cycles, thus the main objective of this study was to perform the cyclic thermal study of this material using TG/DTG-DTA assisted by electron microscopy (TEM and FE-SEM).

\section{Experimental}

\subsection{Materials}

The precursor used was $\mathrm{Zr}(\mathrm{IV})$ butoxide $\left(\mathrm{Zr}\left(\mathrm{OC}_{4} \mathrm{H}_{9}\right)_{4}\right) 80 \mathrm{wt} \%$ solution in 1-butanol and hydrogen peroxide $\left(\mathrm{H}_{2} \mathrm{O}_{2}\right) 30 \mathrm{wt} \%$, both of which were obtained from Aldrich.

\subsection{Preparation of Zirconia nanoparticles $\left(\mathrm{ZrO}_{2}\right)$}

The $\mathrm{ZrO}_{2}$ nanoparticles were prepared by advanced oxidation process and then a hydrothermal process, following the procedures described in [13].

\subsection{Simultaneous Thermogravimetry/Derivative Thermogravimetric- Differential Thermal Analysis (TG/DTG-DTA)}

The TG/DTG-DTA curves were obtained using Netzsch equipment, model STA 449 F3, under the following experimental conditions: $70 \mu \mathrm{L}$ $\alpha$-alumina open crucibles, sample mass of about $11.0 \mathrm{mg}$, heating rate of $10.0{ }^{\circ} \mathrm{C} \mathrm{min}^{-1}$, dry air atmosphere at a flow rate of $50.0 \mathrm{~mL} \mathrm{~min}^{-1}$ and a temperature range of $30.0-1000.0^{\circ} \mathrm{C}$. For the cycle, the temperature range was $30.0-1300.0{ }^{\circ} \mathrm{C}$ (in the first heating) and $650.0-1300.0{ }^{\circ} \mathrm{C}$ (in the second and third heatings).

\footnotetext{
* Corresponding author

E-mail address: caires.flavio@fc.unesp.br (F.J. Caires).
} 

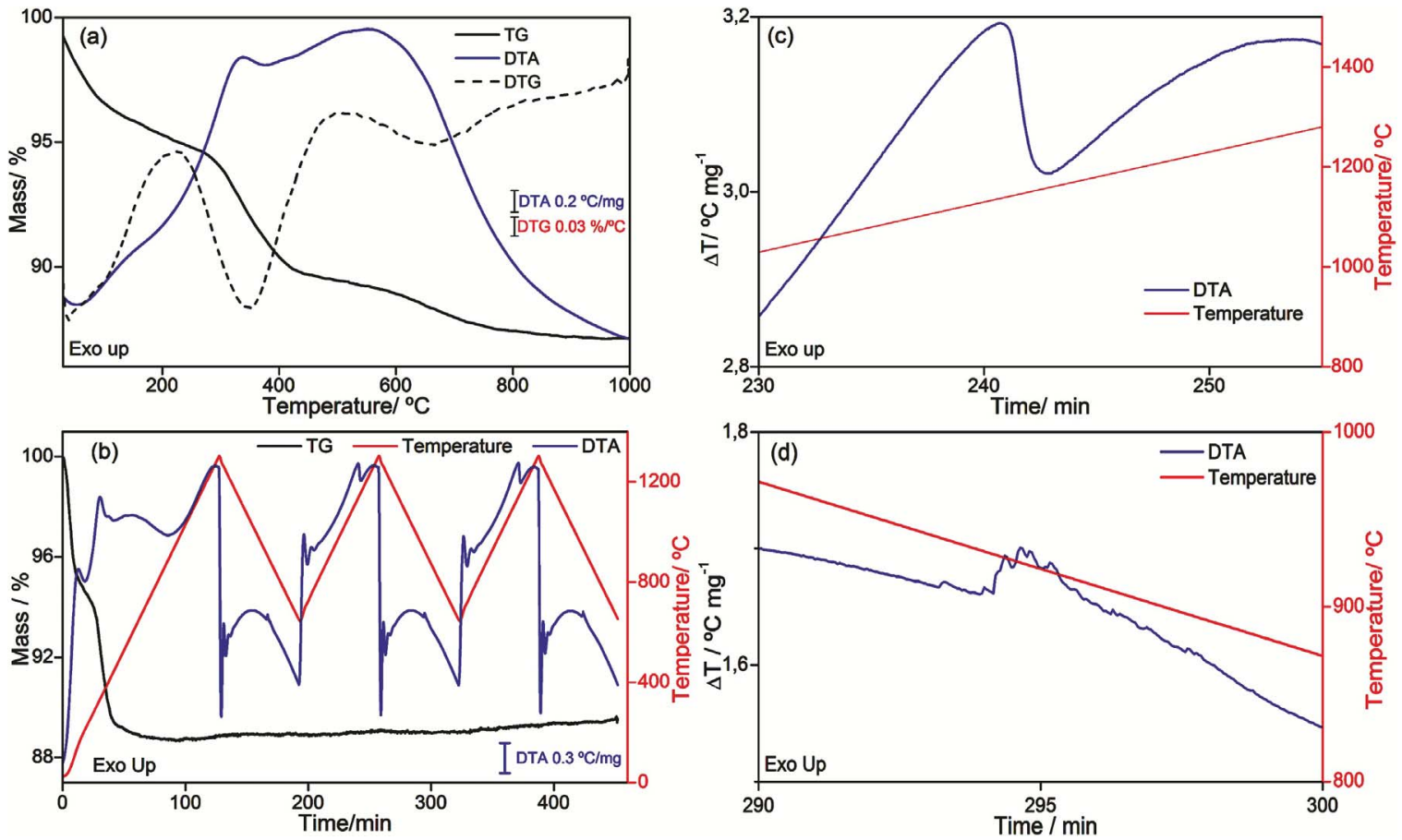

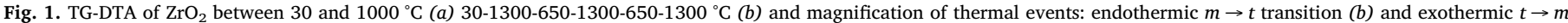
transition $(c)$.

\subsection{Field Emission Scanning Electron Microscopy (FE-SEM) and Transmission Electron Microscopy (TEM)}

To determine the particle size of the $\mathrm{ZrO}_{2}$ from synthesis, it were use images obtained using a transmission electron microscope (TEM, Philips, model CM200), for calcined $\mathrm{ZrO}_{2}$ it were used images from a field emission scanning electron microscopy (FE-SEM, JEOL 7500F). The sample suspensions were prepared in isopropanol using an ultrasound bath to disperse the materials. For the TEM analysis, one drop of this suspension was deposited on a carbon coated copper grid and for the FE-SEM analysis several drops were deposited over a conductive silicon substrate.

\section{Results and discussion}

\subsection{TG/DTG-DTA Analyses}

The TG/DTG-DTA curves for $\mathrm{ZrO}_{2}$ are shown in Fig. 1a. The TG curve shows three steps of mass loss. The first step occurred in the range of $30.0-229.6{ }^{\circ} \mathrm{C}$ with $\Delta \mathrm{m}=5.02 \%$, which was due to the evaporation of water and 1-butanol. The second and third mass loss steps occurred between $229.6-494.8^{\circ} \mathrm{C}$ and $494.8-798.5^{\circ} \mathrm{C}$ and are attributed to the thermal decomposition of residual organic matter, with $\Delta \mathrm{m}_{\text {total }}=7.55 \%$, corresponding to the exothermic events in the DTA curve, with a peak at $338.8^{\circ} \mathrm{C}$ and an exotherm from $388.1-864.5^{\circ} \mathrm{C}$. The residue of $87.53 \%\left(\mathrm{ZrO}_{2}\right)$ was stable until $1000,0^{\circ} \mathrm{C}$. The $\mathrm{ZrO}_{2}$ phase obtained from synthesis was the tetragonal phase $(t)$ [13]. Fig. 1b shows the TG-DTA cycle; the endothermic peak ( $m \rightarrow t$ transition) was not observed in the first heating. However, during the first cooling one exothermic peak was observed in the DTA curve at $902.6{ }^{\circ} \mathrm{C}$, which was attributed to the $(t \rightarrow m)$ transition. These observations confirm the formation of the zirconia phase from synthesis.

Fig. 1b also shows that in each thermal cycle the exothermic peak refers to $(t \rightarrow m)$ transition of $\mathrm{ZrO}_{2}$, was displaced to higher temperatures. However the peak referring to the $(m \rightarrow t)$ transition did not change. For better visualization of these thermal events the magnification of the $m \rightarrow t$ and $t \rightarrow m$ transitions are shown in Fig. 1c and d, respectively. In the first cooling the peak refers to the $t \rightarrow m$ transition occurred at $902.6{ }^{\circ} \mathrm{C}$. In the second and third coolings the peak temperature $\left(T_{p}\right)$ of these events were $923.6{ }^{\circ} \mathrm{C}$ and $934.0{ }^{\circ} \mathrm{C}$ respectively. This displacement could be associated with the growth that the particles underwent during heat treatment; whereas a bigger particle requires higher energy to change its structure, and this consequently occurs at higher temperatures [13]. It is possible to see that the peak associated with the $m \rightarrow t$ transition is larger than the $t \rightarrow m$ peak. This is due to the fact that the $m \rightarrow t$ transition is a diffusion process, in other words it happens at gradative temperatures. Then the particle size does not influence this process [9].

The $t \rightarrow m$ transition is a martensitic event and the multiple peaks in the exothermic event are associated with atomic changes in different particles, which have different sizes $[9,14,15]$.

\subsection{Field Emission Scanning Electron Microscopy (FE-SEM) and Transmission Electron Microscopy (TEM)}

The particles from synthesis (Fig. 2a) had diameters between 4.5-8.5 nm that were dispersed. After the first thermal cycle the $\mathrm{ZrO}_{2}$ particles increased to $300-450 \mathrm{~nm}$ and they were agglomerated (Fig. 2b). The agglomeration of the particles increased at the end of the third cycle (Fig. 2c), which was associated with the particle size: 475-700 $\mathrm{nm}$. These observations evidenced the effect of particle size on the temperature peak of the $\mathrm{ZrO}_{2} t \rightarrow m$ transition.

\section{Conclusions}

The simultaneous TG-DTA data provided previously unreported information about the thermal behavior of $\mathrm{ZrO}_{2}$ nanoparticles. The TGDTA curves of $\mathrm{ZrO}_{2}$ nanoparticles showed the mass losses steps that referred to water and 1-butanol volatilization and the degradation of organic matter. Analyzing the DTA curve cycle and the electron microscopy images it was possible to observe the $m \rightarrow t$ and $t \rightarrow m$ transitions, wherein the last transition showed a higher temperature peak in each cycle. This could be explained by the fact that the increase in particle size requires higher activation energy for the atomic motion 

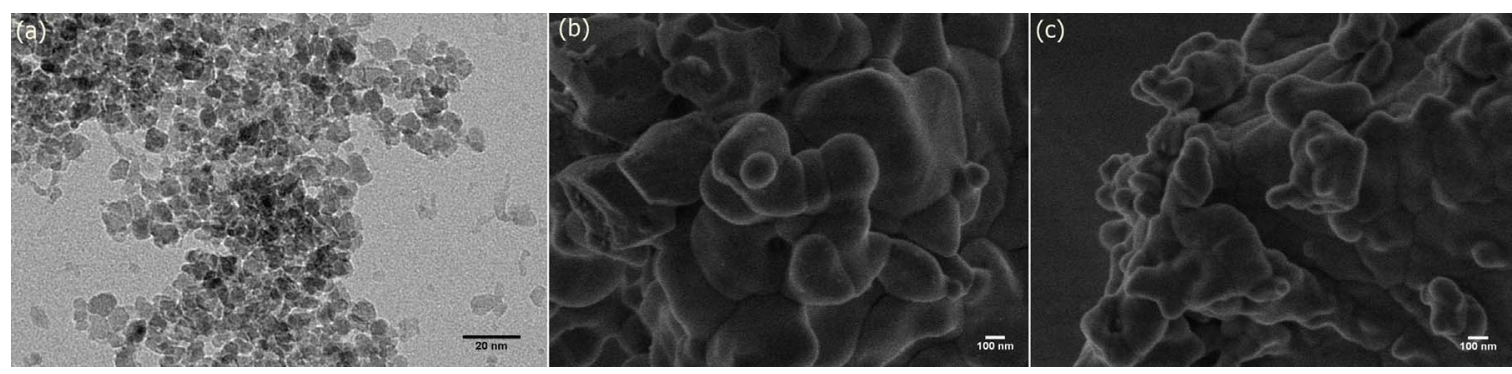

Fig. 2. TEM image of $\mathrm{ZrO}_{2}$ from synthesis (a); FE-SEM images of $\mathrm{ZrO}_{2}$ at the end of the first thermal cycle (b) and the third thermal cycle (c).

to occur.

\section{Acknowledgements}

The authors wish to thank CAPES (proc. 024/2012 Pro-equipment), POSMAT/UNESP, FAPESP (processes: 2012/21450-1 and 2013/090227) for financial support and LMA-IQ for permission to use the FE-SEM and TEM equipments.

\section{References}

[1] J.W. Fergus, Electrolytes for solid oxide fuel cells, J. Power Source 162 (2006) $30-40$.

[2] A. Corma, Inorganic solid acids and their use in acid-catalyzed hydrocarbon reactions, Chem. Rev. 95 (1995) 559-614.

[3] D.Y. Chen, E. Jordan, M. Gell, Thermal and crystallization behavior of zirconia precursor used in the solution precursor plasma spray process, J. Mater. Sci. 42 (2007) 5576-5580.

[4] E. Garcia, P. Miranzo, R. Soltani, T.W. Coyle, Microstructure and thermal behavior of thermal barrier coatings, J. Therm. Spray Technol. 17 (2008) 478-485.

[5] G.D. Wilk, R.M. Wallace, Stable zirconium silicate gate dielectrics deposited directly on silicon, Appl. Phys. Lett. 76 (2000) 112-114.

[6] K. Tanabe, Surface and catalytic properties of ZrO2, Mater. Chem. Phys. 13 (1985) $347-364$.

[7] T. Yamaguchi, Application of $\mathrm{ZrO} 2$ as a catalyst and a catalyst support, Catal. Today 20 (1994) 199-218.

[8] G.Y. Guo, Y.L. Chen, A nearly pure monoclinic nanocrystalline zirconia, J. Solid State Chem. 178 (2005) 1675-1682.

[9] X. Jin, Martensitic transformation in zirconia containing ceramics and its applications, Curr. Opin. Solid State Mater. 9 (2005) 313-318.

[10] H. Baker, Metals Handbook - Introduction to Alloy Phase Diagrams, ASM International, USA, 1992.

[11] J.C. Bressiani, A.H.A. Bressiani, Zirconia based ceramics, INT 20 (1988) 24-27.

[12] S. Kouva, K. Honkala, L. Lefferts, J. Kanervo, Review: monoclínica zircônia, its surfasse sites and their interaction with carbon monoxide, Catal. Sci. Technol. 5 (2015) 3473-4390.

[13] D.S.S. Padovini, D.S.L. Pontes, C.J. Dalmaschio, F.M. Pontes, E. Longo, Facile synthesis and characterization of $\mathrm{Zr} \mathrm{O} 2$ nanoparticles prepared by AOP/hydrothermal route, RSC Adv. 4 (2014) 38483-38490, http://dx.doi.org/10.1039/ c4ra04861j.

[14] R.C. Garvie, The occurrence of metastable tetragonal zirconia as a cristallite size effect, J. Phys. Chem. 69 (1965) 1238-1243.

[15] L.R.F. Rose, The martensitic transformation in ceramics- its role in transformation toughening, Prog. Mater. Sci. 47 (2002) 463-557. 